\title{
Veranderende perspektiewe op seksualiteit en die huwelik in 'n postmoderne kerk
}

\begin{tabular}{|c|c|}
\hline \multicolumn{2}{|c|}{$\begin{array}{l}\text { Authors: } \\
\text { Annelie Botha }{ }^{1} \\
\text { Yolanda Dreyer }^{1}\end{array}$} \\
\hline \multicolumn{2}{|c|}{$\begin{array}{l}\text { Affiliations: } \\
{ }^{1} \text { Department of Practical } \\
\text { Theology, University of } \\
\text { Pretoria, South Africa }\end{array}$} \\
\hline \multicolumn{2}{|c|}{$\begin{array}{l}\text { Note: } \\
\text { This article represents a } \\
\text { reworked version of aspects } \\
\text { from the PhD dissertation } \\
\text { (University of Pretoria), } \\
\text { entitled ' } n \text { Transformatiewe } \\
\text { pastoraat vir die huwelik en } \\
\text { kerk in krisis', with Prof. Dr } \\
\text { Yolanda Dreyer as supervisor. }\end{array}$} \\
\hline \multicolumn{2}{|c|}{$\begin{array}{l}\text { Correspondence to: } \\
\text { Annelie Botha }\end{array}$} \\
\hline \multicolumn{2}{|c|}{$\begin{array}{l}\text { Email: } \\
\text { abothaster@gmail.com }\end{array}$} \\
\hline \multicolumn{2}{|c|}{$\begin{array}{l}\text { Postal address: } \\
\text { PO Box } 50 \text { 333, Mahikeng } \\
\text { South, } 2791\end{array}$} \\
\hline \multicolumn{2}{|c|}{$\begin{array}{l}\text { Received: } 10 \text { Jan. } 2013 \\
\text { Accepted: } 07 \text { Mar. } 2013 \\
\text { Published: } 08 \text { Nov. } 2013\end{array}$} \\
\hline \multicolumn{2}{|c|}{$\begin{array}{l}\text { How to cite this article: } \\
\text { Botha, A. \& Dreyer, Y., } \\
\text { 'Veranderende perspektiewe } \\
\text { op seksualiteit en die huwelik } \\
\text { in 'n postmoderne kerk', } \\
\text { HTS Teologiese Studies/ } \\
\text { Theological Studies 69(2), } \\
\text { Art. \#1917, } 10 \text { pages. http:// } \\
\text { dx.doi.org/10.4102/hts. } \\
\text { v69i2.1917 }\end{array}$} \\
\hline \multicolumn{2}{|c|}{$\begin{array}{l}\text { Copyright: } \\
\text { (C) 2013. The Authors. } \\
\text { Licensee: AOSIS } \\
\text { OpenJournals. This work } \\
\text { is licensed under the } \\
\text { Creative Commons } \\
\text { Attribution License. }\end{array}$} \\
\hline \multicolumn{2}{|l|}{ Read online: } \\
\hline arist & $\begin{array}{l}\text { Scan this QR } \\
\text { code with your } \\
\text { smart phone or } \\
\text { mobile device } \\
\text { to read online. }\end{array}$ \\
\hline
\end{tabular}

Shifting ecclesial perspectives on sexuality and marriage in a postmodern world. The aim of the article is to critically question whether the church is still able to guide people to make meaningful choices with regard to marriage and sexuality when values keep shifting. This question is especially relevant where the church still tends to uphold premodern values (heteronormative, patriarchal, monogamous) with regard to sexuality and marriage as the only (prescriptive) model for marriage in a postmodern world. The article consists of the following sections: changing values versus traditional values; marriage and sexuality from biblical times to the present; church in crisis; and eco-feminist family ethics.

\section{Veranderde teenoor 'tradisionele' waardes?}

Alhoewel die hedendaagse wêreld vinniger verander as ooit tevore in die geskiedenis, vind verandering nie ewe vinnig op alle terreine plaas nie. Die terreine waarop verandering vinnig plaasvind en terreine waarop dit stadig gebeur, kom dikwels in spanning met mekaar. Wanneer hierdie soort spanning ontstaan op die terrein van waardes wat gemeenskappe besonder na aan die hart lê, word dit 'n toutrekverhouding tussen 'vorentoe ter wille van vooruitgang' en 'terug na die tradisie ter wille van die behoud van die goeie'.

Tradisies is sosiale konstrukte wat gemeenskappe in balans hou. Wanneer tradisies verander, word die sosiale balans versteur. Sommige tradisies verander vinnig, soos kleredrag en eetgewoontes, ander verander stadig - so stadig dat dit lyk asof dit onveranderlik is. Dit is in die besonder die geval wat tradisies ten opsigte van identiteit, seksualiteit, taal en etnisiteit betref (kyk Dreyer, Y. 2008:499-527). 'Vaste tradisies' word dikwels as onveranderlik beskou, omdat dit deel van 'n vaste skeppingsorde is. Dit word as God-gegewe eerder as sosiale konstrukte gesien. Hierdie 'vaste tradisies' dra by tot die vorming van identiteit en sosiale rolle. Die huwelik is só 'n tradisie. Die huwelik, seksualiteit en godsdiens funksioneer in noue verbintenis met mekaar (Dreyer, Y. 2011:3).

Alhoewel seksualiteit en die huwelik deel vorm van 'vaste tradisies' wat stadig verander, het dit wel van die Bybelse tyd tot vandag verander. Die sosiale omgewing van die Bybelse wêreld kan in die Oos-Mediterreense (Semitiese) en die Wes-Mediterreense (Grieks-Romeinse) kontekste onderskei word. Hierdie kontekste het aanvanklik afsonderlik van mekaar gefunksioneer, maar het later as gevolg van Hellenisering versmelt. In beide hierdie Mediterreense kontekste was die huwelik, seksualiteit en godsdiens nou met mekaar verbonde. Die waardes wat in die onderskeie kontekste aan hierdie drie entiteite toegeken is, het egter verskil. Dit beteken dat die Bybel nie één duidelike beeld van die huwelik en seksualiteit, en één stel waardes het nie. Die proses van verandering is dus reeds in die Bybel aanduibaar.

Die doel van die artikel is om krities te vra of die kerk nog in staat is om mense sinvol te begelei wanneer waardes ten opsigte van die huwelik, seksualiteit en godsdiens verander. Hierdie vraag is veral ter sake wanneer die kerk steeds die waardes van 'n premoderne wêreld (heteronormatief, patriargaal, monogaam) ten opsigte van seksualiteit en die huwelik as die enigste 'regte model' (hegemonies) vir die huwelik aanbied vir gelowiges wat in 'n namoderne wêreld leef.

\section{Huwelik en seksualiteit: Van die Bybel tot vandag}

Die verandering van die waardes wat aan die huwelik en seksualiteit in die verskillende kontekste vanaf die Bybelse tyd tot vandag toegeken is, word vervolgens kortliks bespreek. Alhoewel daar 'n verbintenis is tussen die huwelik en seksualiteit, is die fokus van hierdie artikel die huwelik en daarom word daar minder aandag geskenk aan die saak van seksualiteit. Die Bybel weerspieël die waardes van die premoderne wêreld waarbinne dit ontstaan het. In die Bybel word die huwelik as metafoor gebruik om die verhouding tussen Jahwe en Israel (Ou Testament - kyk o.a. Hos 1-2; Jer 2-3; Klaagl 1-2; Jes 50:1-3; 54:1-10, Est 16:23; Nah 3:4-7 en Mal 2:11-16) en God en die kerk 
(Nuwe Testament) uit te beeld (kyk Batey 1961:22-24; 1971:70; Ledegang 2001:139-144). Die metafoor van die huwelik word in die Ou Testament aangewend om Israel se ontrou en onvermoë om Jahwe se gebooie te onderhou, aan te dui. Toe Jahwe met Israel 'n verbond gesluit het, het God as ' $t$ ware met Israel 'getrou'.

Die huweliksmetafoor in die Ou Testament kan nie afsonderlik verstaan word van die leer oor die uitverkiesing en die verbond wat voorop staan in die geloof van Israel nie (Batey 1961:42-45; vgl. Botha \& Dreyer 2007:1240). Die verbond tussen God en Israel was bi-lateraal van aard, alhoewel daar nie van gelykheid tussen die partye sprake was nie. Volgens die verbond het Israel sowel as God verpligtinge teenoor mekaar gehad, maar tog het beide partye hulle vryheid van keuse behou. God het die verhouding geïnisieer. Die huwelik in Israel was ook nie 'n verhouding tussen twee gelyke partye nie. Die verhouding is deur die man geïnisieer. Mans het die gesag gehad en vroue het 'n ondergeskikte posisie beklee (Batey 1961:46-47). Vroue se rol binne die gesin was om gehoorsaam te wees aan die wil van hulle mans.

Israel se voortdurende ontrou aan hulle verbond met God, die invloed van die Persiese dualisme, asook die invloed van Hellenistiese denke het aanleiding gegee tot 'n apokaliptiese perspektief. Die blik was gerig op die toekoms wanneer God se beloftes vervul sou word. Die verskuiwing van die fokus van God se teenswoordige betrokkenheid in die lewe van Israel na die vervulling van God se beloftes in die Messiaanse era, het ' $n$ verandering en ontwikkeling van die huweliksmetafoor tot gevolg gehad. Die Rabbyne het die boek Hooglied allegories geïnterpreteer en die huweliksmetafoor verskuif van Israel wat deur verbondsluiting (waarin hulle nou leef) met God getroud is tot Israel wat die Messiaanse (wat in die toekoms sal wees) bruid van God is (kyk Minear [1960] 2004:20).

In die Nuwe Testament word hierdie metafoor van Israel as bruid oorgedra na die kerk. Die Hellenistiese hieros gamos (kyk Bolle 1987:317-321; Budin 2008:14-47; Chavasse [1939] 1940:115-116; Osiek 2002:32) het die evangelieskrywers beïnvloed. Dit bevestig die verband tussen seksualiteit, die huwelik en godsdiens in Israel en in die vroeë Christendom (vgl. Bouyer [1970] 2011:528).

In die Westerse Christelike kerk kan hoofsaaklik vier perspektiewe op die huwelik geïdentifiseer word, naamlik die naturalistiese, sosiale, kontraktuele en die godsdienstige perspektiewe (Witte 1997:2-15; Dreyer, Y. 2011:3). Vanuit die godsdienstige perspektief word die huwelik as 'n spirituele of 'n sakramentele verbintenis gesien. Vanuit die sosiale perspektief word sekere sosiale verwagtings en voorregte aan die huwelik gekoppel, waarvan sommige deur die wet gereël word. Vanuit die kontraktuele perspektief word die huwelik as 'n vrywillige verbintenis gesien wat twee mense aangaan en volgens hulle eie behoeftes reël. Vanuit die naturalistiese perspektief word die huwelik as 'n instelling wat onderhewig is aan the natural laws of reason, die gewete en die Bybel gesien.
Die perspektief dat die huwelik 'n spirituele sakramentele verbintenis is, kom uit Efesiërs 5, waar die hieros gamos, tussen God en mens (gesimboliseer deur die verhouding tussen Jesus en die kerk) beskryf word as 'n mysterion. In die vierde eeu is die Griekse mysterion in Latyn vertaal as sacramentum, wat ' $\mathrm{n}$ 'belofte van trou' beteken. Dit verander die oorspronklike betekenis in Efesiërs, waar die sacramentum oorspronklik verbind is aan die Romeinse militêre mag. 'n Lewenslange verbintenis is van 'n soldaat verwag wat trou gesweer het aan die Romeinse militêre mag (kyk Thatcher 1999:40). Dit is dan die oorsprong van die gedagte dat die huwelik ' $n$ onverbreekbare verbintenis is.

Die huwelik as 'n sakrament kom ooreen met die naturalistiese perspektief op die huwelik, wat die huwelik as 'n instelling van God sien, as deel van die skeppingsorde. Hierdie siening lei tot 'n teologie van die huwelik waarvolgens God die mens gemaak het as man en vrou en daarom het die verbintenis tussen man en vrou godsdienstige belang. Dié wat tot hierdie verbintenis met mekaar toetree, erken en ervaar God se teenwoordigheid en verlossing. Die huwelik as sakrament word gesien as ' $n$ daad van verlossing omdat dit veronderstel is om helend te wees (die sondaar te versoen met God) en mense te verlos van die sonde (kyk Mackin 1982:32; Schüssler Fiorenza 1991:316). Die huwelik as sakrament dien as 'medisyne' (medicinum) en 'remedie' (remedium) teen die 'dodelike siekte' van wellus. Wellus is seks wat nie prokreasie ten doel het nie (vgl. Brooten 2003:187).

Die Protestantse siening van die huwelik stem ooreen met die Rooms-Katolieke naturalistiese perspektief van die huwelik in die sin dat die verbintenis tussen man en vrou as 'n Goddelike instelling gesien is. Die doel van hierdie verbintenis was prokreasie en beskerming. Die kontraktuele aspek van die huwelik as 'n wedersydse ooreenkoms tussen twee persone is ook aanvaar. Die godsdienstige sy van die Protestantse siening van die huwelik verskil van die Katolieke siening in dié opsig dat die huwelik nie as 'n sakrament beskou word nie (vgl. Dreyer, Y. 2011:4; kyk Radford Ruether 2001:75-76). Die huwelik is wel ook in die Protestantse wêreld as 'n sosiale instelling gesien, maar dan deur God ingestel.

Vanaf die agtiende eeu en later het die fokus ten opsigte van die huwelik toenemend na die kontraktuele aspek van die huwelik verskuif. Die denkers van die Verligting het die kern van die huwelik as 'n keuse wat twee mense maak om in ' $n$ intieme verhouding met mekaar te leef gesien, met die gevolg dat 'God was no longer to be viewed as an active agent in the daily affairs of human beings, including their daily marital lives' (Witte 1997:197). Hoe hierdie verhouding ingerig sou moes word, is volgens hulle nie vooraf bepaal deur God of die natuur, of soos voorgeskryf deur die kerk, staat, tradisie of gemeenskap nie, maar slegs deur wat die twee persone self ooreenkom. Die algemene voorskrifte van 'beskaafde samelewings' soos: respek vir lewe, vryheid, veiligheid, gesondheid en die algemene welstand van mense moes nagekom word (Witte 1997:10). Vir die fyner punte van hulle verhouding was hulle egter self verantwoordelik. Hiermee het die tradisionele Westerse (godsdienstige) siening van 
die huwelik in die spervuur gekom (kyk Glendon 1989). Pertinente sake waaroor debat gevoer is, was:

- in hoeverre ouers se toestemming nog nodig was as dit net ' $n$ besluit tussen individue behels

- wat die rol van die kerk nog sou wees as individue soveel vryheid en beskikkingsreg het

- of die vereiste dat daar getuies moet wees nog geld indien die klem nie meer op die sosiale en wetlike aspekte is nie, maar op die individuele

- die absolute posisie van heteroseksuele monogamie is bevraagteken

- en die volle gelykheid tussen man en vrou is as vooronderstelling aanvaar en dit het ingedruis teen die tradisionele 'hoofskap' van die man.

Hierdie idees was egter so radikaal dat dit nie daarin kon slaag om die denke oor die huwelik in die negentiende eeu te transformeer nie (Witte 1997:11-12; kyk Dreyer, Y. 2011:4). Dit het egter beter beskerming vir kinders en vroue ten opsigte van hulle liggaam en eiendom tot gevolg gehad en dit het die basis vir die veranderings wat ten opsigte van die huwelik gekom het in die twintigste eeu gevorm. Die fokus het toenemend na die belange van die twee betrokke partye en hulle verwagtings ten op sigte van die huwelik verskuif (vgl. Matouschek \& Rasul 2008:60). Eksterne gesaginstansies soos die kerk, ouers en die gemeenskap het nie meer die primêre seggenskap gehad nie. Die gevolge van hierdie verskuiwings was dat voorhuwelikse kontrakte toenemend gesluit is, dat egskeidings nie meer op die skuld-grondslag beredder is nie en dat die reg op privaatheid rakende seksuele sake toenemend erkenning begin geniet het (kyk Parkman 1993:91-106). Daarmee saam is ander seksuele oriëntasies buiten heteroseksualiteit toenemend aanvaar (vgl. Ekelaar 2006:179). Seksuele gedrag sonder die toestemming van die ander persoon het strafbaar volgens die wet geword. Dit het selfs sover gevorder dat verkragting binne die huwelik deur die staat erken word.

In sy boek, Marriage after modernity, Christian marriage in postmodern times, verduidelik Adrian Thatcher (1999) hoe die huwelik gesien is as 'n universele instelling, wat vanuit 'n teologiese oogpunt vanaf die skepping bestaan het. Die huwelik is gesien as deel van hoe dinge is, hoe die sosiale wêreld van verhoudings werk. Die huwelik is as die instelling by uitnemendheid gesien waarin mense hulle liefde teenoor mekaar uitleef. Hierdie liefde behoort 'n weerspieëling van God se liefde vir mense te wees. Mans en vroue in die huwelik is tegelyk die bemiddelaars en ontvangers van God se relasionele liefde wat gelei het tot die skepping en herstel van die wêreld deur Christus. Die huwelik is as 'n sakrament, die locus van Goddelike liefde en genade beskou.

Hierdie siening van die huwelik kom egter nie ooreen met die ervaring wat die meeste getroude en post-getroude mense het nie. Adrian Thatcher (1999:9) wys daarop dat die teologie van die huwelik waarskynlik in elke tydvak nie ooreengestem het met dit wat ervaar is in die huwelik nie, en dat dit in besonder die geval is met vroue se ervaring van die huwelik. Die heersende sienings van die Christelike huwelik word ongeloofwaardig wanneer dit nie die gaping tussen die God-gegewe doel van die huwelik, asook die sakramentele aard daarvan, en die eksistensiële werklikhede van mense se ervaring van die huwelik erken nie (vgl. Dreyer \& Van Aarde 2007:626). Die doel van die huwelik het dikwels meer daaroor gegaan om wettige erfgename te bekom en om beheer uit te oefen oor voortplanting. Volgens Rosemary Haughton (1987:141-154) is die mooi-klinkende kerklike uitsprake oor die huwelik dikwels niks anders nie as 'a theology of marriage shattered by experience'. Adrian Thatcher (1999:10) stel dit soos volg: 'Marriage is frequently discovered to be a violent, loveless institution, and increasingly it is delayed, avoided and terminated. Fewer people are marrying.' Volgens Cooper-White (1995:166) is die feit dat die huwelik gevorm en beïnvloed is deur patriargale denke en gebruike, die rede waarom daar soveel geweld en misbruik in huishoudings voorkom. Die vraag is waarom die ideologie (teologie) van die huwelik so ver verwyder geraak het van die eksistensiële ervarings van mense (en veral vroue) in die huwelik. Dit is daarom noodsaaklik dat die werklikhede van die huwelik en die belange van beide huweliksvennote in ag geneem word, wanneer 'n Christelike teologie van die huwelik ontwikkel word. So 'n teologie van die huwelik sal, soos enige teologie, die gelykheid van alle mense, dus ook van mans en vroue in die huwelik, moet aanvaar as evangeliese uitgangspunt.

Adrian Thatcher (1999:11) wys egter daarop dat geen Christelike teologie van die huwelik volledig en voldoende sal kan wees vir elke tydvak en konteks nie. 'Die gaping tussen bestaande teologiese teorieë en die ... [praktyk] is so groot dat dit teologiese refleksie bemoeilik, omdat daar uiteenlopende interpretasies bestaan' (Dreyer \& Van Aarde 2007:628). Daar is nie 'n 'enkelvoudige perspektief op die huwelik in die Bybel te vind nie', en daarom is dit belangrik om in verskillende en veranderde 'kontekste telkens weer ander perspektiewe op die huwelik [te] vind' (Dreyer \& Van Aarde 2007:630; Thatcher 1999:11).

Adrian Thatcher (1999:12; vgl. Dreyer \& Van Aarde 2007:628) ondersoek vanuit 'n Bybelshermeneutiese perspektief die Bybelse huweliksmodelle en identifiseer ses basiese uitgangspunte, wat as vertrekpunte dien:

- lojaliteit teenoor Jesus Christus

- die Bybel

- tradisie

- ervaring

- kultuur

- die mense van God.

Stephen Barton (1996) stel die volgende vrae wat belangrik is vir die ontwikkeling van 'n teologie van die huwelik:

Instead of asking, is the Bible good news for human sexuality?, the question we should be asking is much more of the kind, what sort of people ought we to become, so that we are enabled to read the Bible in ways which are life-giving in the area of gender and sexuality? What if the Bible is more like the text of a Shakespearean play or the score of a Beethoven symphony, where true interpretation involves corporate performance and practical enactment, and where the meaning of the text or score will vary 
to some degree form one performance to another depending on the identity of the performers and the circumstances of the performance? (bl. 4)

Diegene wat 'n teologie van die huwelik ontwikkel, moenie uit die oog verloor dat daar maniere was en is om die Bybel te lees wat nie lewe-gewend is nie, en waar diskriminasie teen vroue, kinders, slawe, Jode en mense van ander ras of kleur, deur ' $n$ beroep op die Bybel gemagtig en genormaliseer is (kyk Thatcher 1999:14). Dit gebeur dat maghebbers se stemme eensydig gehoor word en die onvoorwaardelike liefde van God daardeur uitgedoof word (kyk Dreyer \& Van Aarde 2007:629). Lojaliteit teenoor Jesus word nie eerste gestel nie. Lojaliteit teenoor tradisie moet in die lig van lojaliteit teenoor Jesus hanteer word. Daar moet in gedagte gehou word dat die getuienis van die Ou en Nuwe Testament uit'n spesifieke kulturele konteks en tradisie kom. Dit beteken dat daar onderskei moet word tussen wat blywende waarde het en wat van verbygaande aard is. Ten opsigte van die huwelik, stel Ralph Brown (1990) dit soos volg:

We need to appreciate that while at the heart of the work of the Church's Courts is the fact that marriage is an unchanging reality, society's perception of this reality does change. (bl. 13)

Dit is dikwels die geval dat tradisie die belange van die dominante groep reflekteer en nie dié van almal nie -die belange van gemarginaliseerdes word nie in ag geneem nie. Binne die tradisionele siening het die huwelik dikwels as 'n konstruk gedien wat patriargale belange in stand hou. Dit is dus duidelik dat alleenlik lojaliteit teenoor die tradisie nie moontlik is nie. Ander lojaliteite wat hierdie lojaliteit behoort te oorwoeker as 'n teologie van die huwelik getrou wil wees aan die evangelie en respekvol teenoor mense, is die volgende:

\section{Lojaliteit teenoor Jesus Christus}

Wanneer daar op lojaliteit teenoor Jesus Christus in die nadenke oor ' $n$ Christelike teologie van die huwelik gefokus word, sal die bestaande konstruk wat hoofsaaklik die belange van een vennoot in die huwelik dien, verander of getransformeer moet word tot iets wat meer getrou is aan die evangelieboodskap. Om hierdie verandering teweeg te bring, is respek vir die ervaring van ander nodig. Daar behoort geluister te word na diegene wat stemloos gelaat is deur die patriargale tradisie, na vroue wat vasgevang is in 'n patriargale instelling. Wanneer die ervaring van mense ernstig opgeneem word, kan die gaping tussen tradisie en die eksistensiële werklikhede van die lewe oorbrug word.

\section{Lojaliteit teenoor die kultuur}

Lojaliteit teenoor die kultuur gaan oor die besef dat die huwelik ' $n$ eietydse kultuurinstelling is, en dat ' $n$ mens toeganklik behoort te wees daarvoor dat die Heilige Gees ook buite die grense van die kerk kan werk. Indien daar teenkanting teen verandering is, behoort dit uit die evangelie gemotiveer te word en nie net ' $n$ poging tot die handhawing van die status quo te verteenwoordig nie (Thatcher 1999:23).

\section{Lojaliteit teenoor God se mense}

Lojaliteit teenoor God se mense beteken dat daar nie net geluister behoort te word na teoloë nie, maar na al God se mense (vgl. Dreyer \& Van Aarde 2007:629).

Die huwelik as historiese en sosiale instelling kom onder skoot wanneer paradigmas verskuif. Wanneer so 'n verskuiwing plaasvind, word tradisionele maniere van dink bevraagteken. Dit was ook so ten opsigte van denke oor die huwelik in die oorgang van die moderne na die postmoderne era. Die huwelik, wat tradisioneel beskou is as 'n gevestigde instelling wat mense se seksualiteit reguleer, het in 'n krisis beland toe sienings oor seksualiteit en die huwelik as instelling verander het. Hierdie paradigmaverskuiwing bring mee dat ' $n$ einde gebring moet word aan alle vorme van patriargie en alle instellings wat berus op patriargale mag (kyk Weeks 1995:25-26). Hodgson (1994) beskryf die omvang van die krisis waarin die huwelik as instelling is soos volg:

The sexual crisis unmasks the linkage of religious belief with sexual repression and calls into question the authority of scripture on issues vital to human sexuality, while the gender crisis is disrupting long-established ways of imaging divine power and presence, namely in androcentric an patriarchal terms. (bl. 62)

Die huwelik het 'n fokuspunt van konflik tussen die verskillende kerke geword. Thatcher (1999:31-66) meen dat Christene in die postmoderne era in verskillende gesprekke betrokke behoort te raak. Die een is die interne gesprek tussen Christelike kerke oor die verskillende uitgangspunte oor die huwelik en die ander is die eksterne gesprek met die sekulêre gemeenskap wat nie meer meen dat wat die Christendom sê ten opsigte van die huwelik, relevant is nie. Kwessies wat aandag behoort te geniet in die interne gesprek is onder andere die volgende:

- verskillende sienings oor die huwelik binne die Nuwe Testament

- of egskeiding Bybels gesproke toelaatbaar sou kon wees

- of die huwelik 'n sakrament behoort te wees of nie

- hoe gemaak met die feit dat die Christelike tradisie positief en negatief praat oor die huwelik?

- dat dikwels net mans voorskrifte vir die huwelik bepaal het

- watter verwagtings by vroue en mans op grond van die heersende teologie van die huwelik geskep word

- die feit dat vroue in die huwelik slegter daaraan toe is as mans (kyk bv. Clark \& Haldane 1990:27)

- of patriargie bepalend is vir die huwelik en of 'n niepatriargale huwelik 'n sosiale moontlikheid is (kyk bv. Thatcher 1999:45).

Die eksterne dialoog tussen die Christelike tradisie en dié wat die Christelike tradisie gedeeltelik of in die geheel verwerp, beklemtoon volgens die outeurs die feit dat die kerk inderdaad ten opsigte van die huwelik as instelling in 'n krisis verkeer (kyk Dreyer \& Van Aarde 2007:630).

Adrian Thatcher (1999:67) identifiseer verskillende huweliksmodelle in die Bybel: 'Hy verkies om die woord 
'model' te gebruik, omdat 'n model nooit gelykstaande is aan wat dit voorstel nie' (Dreyer \& Van Aarde 2007:631). 'n Model bied maar ' $n$ blik op die groter realiteit. Thatcher onderskei tussen twee hoofmodelle en drie ander modelle in die Bybel. Die twee hoofmodelle is eerstens die 'verbond' as model vir die huwelik en tweedens die model van 'eenwording'. Die ander drie modelle vir die huwelik wat in die Bybel voorkom, is die model van die huwelik as 'twyfelagtige noodsaaklikheid', die huwelik as 'toegewing aan die wêreld' en laastens die huwelik as 'passievolle wedersydse liefde'.

Vanaf die agste eeu v.C. is die huwelik reeds as 'n verbond gesien. Hierdie verbond is gemodelleer op die God-mens verbond tussen Jahwe en Israel (Thatcher 1999:68; vgl. Batey 1961:42-47). Volgens Anderson (1993:138) bestaan'n verbond uit " $n$ toegewyde verhouding, wat ... [vir beide partye] beloftes en verpligtinge insluit en gewoonlik deur 'n ritueel ... [beseël] word' (Dreyer \& Van Aarde 2007:631). Palmer (1972:618) beklemtoon die onderskeid tussen 'n verbond en 'n kontrak. In die geval van 'n kontrak is dit mense wat as getuies dien en verseker dat dit afgedwing sal word, 'terwyl God of gode hierdie funksie by'n verbond vervul. ...'n Verdere ... kenmerk van 'n verbond is die ongelyke verhouding tussen die twee partye' (Dreyer en Van Aarde (2007:631). 'n Voorbeeld hiervan is die verhouding tussen God en die volk van God. God bly altyd getrou aan die verbond, terwyl die volk ontrou en ongehoorsaam is. Dreyer en Van Aarde (2007:631-632) onderskei tussen twee strome binne die Reformatoriese teologie wat twee verskillende Latynse woorde vir 'verbond' gebruik het: Die eerste is die term, foedus, wat deur die Zürichse Hervormers beklemtoon is, insluitend Zwingli en Bullinger. Wanneer foedus as die vertaling van die woord, verbond, gebruik word, 'veronderstel dit 'n [bi-laterale] verhouding: 'n ongelyke verhouding waar God die inisiatief neem, maar waar die mens ook keuses kan ... [uitoefen]. [Testamentum] is die Latynse woord vir verbond wat veral deur Calvyn gebruik is, en 'n verhouding veronderstel waar God eensydig inisiatief neem en die mens eintlik geen keuse het nie' (Dreyer en Van Aarde 2007:631). Calvyn het hierdie term gekies omdat dit op sy siening van die uitverkiesing gegrond is (vgl. Milner 1970:46-58).

'Om die verbondsmodel ... [vir] die huwelik te gebruik klink aanvanklik [goed], omdat dit gebaseer is op die verhouding tussen God en die geloofsgemeenskap ...' (Dreyer \& Van Aarde (2007:631). Dit blyk egter problematies te wees omdat 'n verbond 'n ongelyke verhouding veronderstel. Volgens Thatcher (1999:69) lei so 'n siening daartoe dat vroue gestereotipeer word as die minderwaardige en ontroue party in die huweliksverbond, soos Israel was in die verbond met God. In Hosea word die huweliksmetafoor nie net gebruik om Israel se eksklusiewe aanbidding van Jahwe te beklemtoon nie, maar ook die ongelykheid tussen Jahwe en Israel (Yee 2001:380).

Hosea gebruik sy huwelik met die ontroue Gomer 'as 'n model vir die gebroke verbond tussen God en die volk. Liefde en ... [vergifnis] speel hier 'n belangriker rol as wette en geregtigheid ...' (Dreyer \& Van Aarde 2007:632). Hosea vergewe sy vrou en neem haar terug. God doen dieselfde met die volk Israel. Dit is egter steeds 'n ongelyke verhouding, want alle seggenskap lê by God. Na analogie van die verbondsverhouding tussen God en die volk, stel die man God voor, terwyl die vrou aan God se ongehoorsame volk gelykgestel word. Hierdie vergelyking is ook problematies omdat Hosea seksuele geweld 'gebruik om sy vrou terug te kry. Weems (1989:101) wys uit dat dit vir vroue wat slagoffers was van seksuele geweld, 'n ondraaglike metafoor is om God voor te stel as 'n woedende eggenoot. Jeremia en Esegiël gebruik ook 'n gebroke huwelik om die verhouding tussen God en die volk voor te stel' (Dreyer \& Van Aarde 2007:632).

Thatcher (1999:72) beklemtoon veral hier die feit dat 'God die een is wat die egskeiding inisieer. Hy identifiseer ook verskeie ... [stereotipes] wat deur hierdie teksgedeeltes gekondoneer word en kom ... tot die gevolgtrekking dat hierdie verbondsmodel nie net so ... [op die] Christelike huwelik ... toegepas kan word nie' (Dreyer \& Van Aarde 2007:632). Thatcher (1999:72-72; vgl. Dreyer \& Van Aarde 2007) beskryf die stereotipes en hulle gevolge soos volg:

... women can't be trusted; women are naturally randy and unfaithful; prostitutes like sex; women's beauty is a source of sin; women deserve violence and humiliation as legitimate punishment. Even the depiction of a fresh start, the new covenant, will induce a state of disabling female guilt, the weight of which renders women dumb and makes mutual participation in the covenant impossible. (bl. 632)

In Deutero-Jesaja verskuif die beeld van God as 'n man wat kwaad en veronreg is in 'n huweliksverbond, na die beeld van 'n verbondsliefde tussen God en Israel wat nie verbreek kan word deur menslike ontrou nie (Thatcher 1999:73). In die laaste boek van die Ou Testament, Maleagi, word die Joodse huwelik uitdruklik as 'n verbond beskryf. Die profeet Maleagi word 'kwaad vir die Israelitiese mans omdat hulle van hulle vroue skei om met heidense vroue te trou. Deur dit te doen, verbreek hulle die verbondsolidariteit met God ...' (Dreyer \& Van Aarde 2007:633; vgl. Mackin 1982:39). Die verbreking van die huweliksverbond word in verband gebring met die verbreking van die verbond met God. Dit het implikasies vir die hele volk en nie net vir individue wat skei nie. Maleagi oordeel dat egskeiding verkeerd is omdat dit selfsugtig is en lewer kritiek teen die ongelyke mag wat mans oor vroue uitoefen (Thatcher 1999:74; vgl. Dreyer \& Van Aarde 2007:633).

Die huwelik gesien as 'n verbond kom uit die konteks van 'n patriargale samelewing. Patriargie is die wetlike, ekonomiese en sosiale stelsel wat die regering oor die rol van die manlike gesinshoof aanvaar. Dit beteken dat vroue, kinders, werkers en eiendom ondergeskik is aan manlike gesinshoofde. Die verhouding tussen man en vrou in die huwelik word beïnvloed deur die patriargale samelewing (kyk Moore 2002:111).

Die konteks van die huwelik in Israel was die patriliniêre en patrilokale familiestruktuur en die eer en/of skaamtewaardesisteem (Yee 1992:209; vgl. Malina 1993:124). In so 'n familiestruktuur is die kinders as deel van die man se familie 
gesien en die seuns was die erfgename. Vroue het saam met hulle man by sy familie gaan woon. Vir vroue is hulle huwelik deur hulle pa gereël. Vroue se primêre bydrae tot die huishouding was hulle liggaam en seksualiteit. Vroue moes kinders, en verkieslik seuns, in die wêreld bring, sodat die man se nageslag voortgesit kon word en die seuns die land en besittings kon erf. Daarom is die seksualiteit van vroue en dogters streng beheer en teen buite-inmenging beskerm. Binne die eer en/of skaamte-waardesisteem was egbreuk die ergste oortreding wat ' $n$ vrou kon begaan, omdat dit die eer van haar man aangetas het en die vaderskap van haar kinders betwyfel kon word. 'n Dubbele standaard het ten opsigte van die reëls vir mans en vroue wat egbreuk pleeg gegeld. Buiteegtelike seksuele aktiwiteite wat onaanvaarbaar was vir die vrou, was toelaatbaar vir mans (Yee 1992:210).

Vroue se plek in die tradisioneel patriargale huishouding bepaal hulle identiteit en dien terselfdertyd as voorskrif vir hoe hulle moet optree (Jacobs-Malina 1993:3). Binne die huishouding was dit vroue se taak om te help toesien dat mans die sentrale posisie beklee. Derhalwe moes vroue hulle onderwerp aan hulle mans binne die huishouding wat eintlik die enigste sfeer was waar vroue kon funksioneer. Vroue moes hulle weerhou van gedrag wat die eer van hulle mans kon skade berokken en hulle moes kuis wees (Malina 1993:53).

Nie Jesus of Paulus gebruik die term, verbond, wanneer hulle praat oor die huwelik nie. Omdat die term 'verbond' toenemend in verband gebring is met die begrip 'onfeilbare liefde', bespreek Thatcher (1999:75) die perspektief van die Deutero-Pauliniese boek, Efesiërs en hoofsaaklik Hoofstuk 5 ook onder die verbondsmodel. Hoewel die outeur van Efesiërs nie van die term, verbond, gebruik maak nie, kan 'n verbondsperspektief op die huwelik afgelei word uit die analogie tussen mans en Christus en vroue en die kerk. Die teks is in die verlede gebruik om Goddelike sanksie te verleen aan die onderdanigheid van vroue teenoor mans, asook aan die 'onverbreekbaarheid van die huwelik'.

Efesiërs is een van drie plekke in die Nuwe Testament waar die Haustafeln [huistafels] voorkom. Hoewel Efesiërs 5:22 Christene (mans en vroue) oproep om aan mekaar onderdanig te wees, beteken dit nie dat vroue en mans gelyke status gehad het nie. Inteendeel, Efesiërs 5:22-24 gebruik bogenoemde analogie om die onderdanigheid van vroue aan hulle mans in alles te motiveer en teologies te regverdig. So word die ondergeskikte posisie van vroue in die huweliksverhouding deur die Christologie van Efesiërs gevestig (Tanzer 1994:335) en word onderdanigheid iets wat van vroue verwag word ('a woman thing') (Osiek 2002:31).

'n Suid-Afrikaanse Nuwe Testamentikus, Elna Mouton (2003:59-87), interpreteer Efesiërs as 'hermeneutiek van die oorsteek van grense' (liminality) (vgl. Taylor 1990:199-208). Die konsep van 'liminaliteit' word deur die Franse antropoloog, Arnold van Gennep ([1909] 1960), gebruik in verband met 'rites de passage', [oorgangsrituele], vir mense wat van een lewensfase na 'n volgende oorgaan (Deflem 1991:1-25). In haar 'hermeneutiek van liminaliteit' gaan dit vir Mouton (2003:62) daaroor dat die Efesiërs-teks die oorspronklike lesers se beweging en groei van een wêreld na 'n ander, van hulle posisie buite Christus na hulle posisie in Christus, beskryf. Liminaliteit is ' $n$ proses van losmaak van die bekende en bestaande, van verandering en vorm gee aan ' $n$ nuwe identiteit in Christus. Dit is 'n proses van herinterpretasie.

Die Efesiër-gemeenskap was in 'n voortdurende proses van herwaardering en herinterpretasie van hulle tradisies, taal en optrede in die lig van die evangelie van Jesus Christus. Hierdie voortgaande proses van reoriëntasie dien as 'n waarskuwing teen enige vorm van morele stagnasie, valse stabiliteit, absolute sekerheid en 'n geslote etiese sisteem (kyk Mouton 2003:62). Hierdie proses waarin die Efesiërs moes leer om hulle nuwe identiteit met 'n leefstyl wat waardig is aan hulle roeping te laat ooreenstem, vind plaas in die 'liminale spanning' tussen onthou en hoop. Terwyl hulle onthou hoe hulle voorheen was en geleef het, onthou hulle ook wat God in Jesus Christus vir hulle gedoen het, en word hulle hoop lewend gehou deur hulle manier van lewe in hulle daaglikse ontmoeting met die opgestane Christus en die Heilige Gees. Die dryfkrag vir verandering in die Efesiërs-teks is die lesers se nuwe identiteit in Christus (Mouton 1995:73). Wanneer dit die lens is waarmee Efesiërs 5:21-33 gelees word, is Christus se selfopofferende liefde die motivering om onderdanig te wees aan mekaar (Mouton 1995:73-74; kyk Mouton 2003:64). Wanneer mans hoor dat hulle die hoof van hulle vroue is soos Christus die hoof van die kerk is, is dit belangrik om te onthou dat Christus se hoofskap gekwalifiseer word in terme van die krag van sy liefde, wat geopenbaar word in selfopofferende liefde (vgl. Botha \& Dreyer 2007:1267-1268.

Vanuit die 'evangelikaalse' tradisie lees Virginia Mollenkott (2003:53-55) die opdrag wat mans ontvang om hulle vroue lief te hê soos hulle eie liggame in die lig van die liefdesgebod: 'Jy moet jou naaste liefhê soos jouself' (Matt 22:37-40). Mollenkott (2003:45-58) wil fokus op die bevrydende elemente in die Efesiërs-teks, naamlik dat daar in Efesiërs 5:21 die oproep is tot wedersydse onderdanigheid van Christene aan mekaar, as gevolg van hulle lewe in Christus, sonder enige verwysing na geslagsrolle. Hierdie beginsel van wedersydse onderdanigheid in Christus is bepalend vir die verstaan van Efesiërs 5:21-33. Hierdie beginsel roep vroue en mans op tot wedersydse onderdanigheid aan mekaar, op grond van hulle lewe in Christus. Wanneer elke verhouding verstaan word as in Christus, word die patriargale hiërargie omvergewerp en gelykheid gevestig. Die tweede bevrydende element in Efesiërs 5:21-22 is dat daar ' $n$ duidelike grens gestel word aan die analogie van mans met Christus. Mans ontvang die opdrag om hulle vroue lief te hê soos wat Christus die kerk liefhet (vgl. Botha \& Dreyer 2007:1268-1269).

Dit is hierdie opdrag wat vir die oorspronklike hoorders van Efesiërs 5:21-33 so radikaal anders is as wat die gebruike van hulle tyd was. Liefde was byvoorbeeld nie van primêre belang in die huwelik nie (kyk Malina 1993:127). Nou is dit 'n opdrag. Volgens Mollenkott (2003:49) word daar met hierdie analogie van mans verwag om hulle patriargale voorregte 
neer te lê en in nederigheid tot voordeel van hulle vroue op te tree. Christus se vrywillige neerlegging van sy 'bestaan op Godgelyke wyse' (Fil 2:5) is die voorbeeld wat aan mans gestel word. Die opdrag aan vroue en mans is om in die huwelik teenoor mekaar op te tree soos hulle teenoor Christus en in Christus optree (vgl. Botha \& Dreyer 2007:1267-1268).

Die verskil in die opdrag aan mans en die opdrag aan vroue het egter daartoe bygedra dat die verskil in vroue en mans se status in die huwelik gehandhaaf is, in plaas daarvan dat almal se status in Christus tot groter gelykheid vir vroue gelei het. In die interpretasie van die analogie in die teks, is daar telkens gekies om te bly fokus op die patriargale verhouding van subordinasie deur te verwys na die hiërargies-bepaalde verhouding tussen Christus en die kerk (kyk Schüssler Fiorenza 1993:170). Die gevolg hiervan is dat die aanvanklike bevryding vir vroue op grond van Paulus se prediking (Gal 3:28) hulle ontneem is en hulle weer gebuk moes gaan onder die konvensionele patriargale moraliteit. Dit bevestig dat kulturele waardes 'n deurslaggewende rol in Bybelinterpretasie gespeel het en steeds speel (kyk Dreyer \& Van Aarde 2007:635).

Die volgende model wat Thatcher (1999:77) bespreek ten opsigte van die huwelik is die model van 'vleeslike' eenwording. 'Hierdie model kan teruggevind word in Genesis 2:23-24. Veral die ... opmerking van vers 24 is belangrik: "Daarom sal 'n man sy vader en moeder verlaat en saam met sy vrou lewe, en hulle sal een word" (Gen 2:24). Dit word "eenheid van die vlees" genoem omdat dit oorspronklik ... [afkomstig is] van die metafoor dat die vrou vanuit die vlees van die man gevorm is. Dit het ook te doen met seksuele gemeenskap. Die twee, man en vrou, word 'n totale nuwe eenheid. In die Ou Testament kom hierdie model, behalwe vir hierdie gedeelte in Genesis, nie weer voor nie' (Dreyer \& Van Aarde 2007:634-635; vgl. Thatcher 1999:78). In die Evangelie van Markus haal Jesus hierdie gedeelte aan, met die verdere opmerking dat die man en vrou ná eenwording nie meer twee individue is nie, maar een in vlees. Omdat God hulle saamgevoeg het, mag niemand hulle skei nie (Mk 10:8-9). 'Markus 10:5-9 handel oor Jesus se antwoord op die vraag van die Fariseërs oor 'n aanvaarde gebruik in sy tyd, te wete dat 'n man, op grond van Deuteronomium 24:1, van sy vrou kan skei deur aan haar 'n skeibrief te gee' (Dreyer \& Van Aarde 2007:635).

'Die "eenheid van vlees" veronderstel 'n persoonlike eenheid wat aan beide man en vrou 'n nuwe identiteit verleen ... Daarom is hierdie relasie ... permanent' (Dreyer \& Van Aarde 2007:636). God is nie net getuie van eenwording nie, maar is ook die een wat dit bekragtig, wat dit so 'gewil' het. Dit maak dat egskeiding en poligamie dus nie geregverdig kan word nie (vgl. Thatcher 1999:79-80). 'Volgens Paulus is hierdie "eenheid van vlees" 'n rede waarom Christenmans nie met prostitute omgang mag hê nie' (Dreyer \& Van Aarde 2007:636). Paulus gebruik dieselfde argument as Jesus. Paulus meen dat die vleeslike eenwording wat plaasvind tussen 'n prostituut en Christen-man nie die eenheid is wat Jesus in gedagte gehad het nie. In 1 Korintiërs 7 word iets sigbaar van Paulus se verstaan van hierdie eenwording van man en vrou. Thatcher (1999:80) stel dit soos volg: 'The unity which they make as a couple vetoes any sexual independence which they may once have had as single people.'

In Efesiërs word die vleeslike eenwording 'n stap verder geneem met die argument 'dat 'n man, deur sy vrou lief te hê, ook homself liefhet. Hierdie twee liggame wat een geword het, behoort [beklemtoning A.B.] nie net aan mekaar nie, maar die twee mense is ook mekaar. "Self"-liefde kry dus in die Christelike huwelik 'n nuwe betekenis ... ['n Mens is mens in die verhouding met ander]. So kry die getroude persoon dus 'n nuwe identiteit' (Dreyer \& Van Aarde 2007:636; vgl. Thatcher 1999:80). Die outeur van die Efesiër-brief lewer kommentaar op Genesis 2:4: 'Hierin lê daar 'n diep "geheimenis" opgesluit, en ek pas dit toe op Christus en die kerk' (Ef 5:32). Die skrywer van Efesiërs pas die Genesis-teks toe op Christenskap. Thatcher (1999:81) stel dit soos volg: 'Christ's love is thought to exemplify the love which the writer believes is to be found in the one-flesh union of Genesis.'

In sy bespreking van die model van die huwelik as 'twyfelagtige noodsaaklikheid', begin Thatcher (1999:81) by die Hebreeuse wysheidsliteratuur wat sowel waardering as agterdog teenoor die huwelik vertoon. Die denke oor die huwelik is androsentries van aard. Inhierdieliteratuur is vroue almal dieselfde: vroue is die objek van passie, bewondering, sorg en dankbaarheid, maar ook van agterdog en selfs haat (kyk Dreyer \& Van Aarde 2007:636). Mackin (1982:50) stel dit soos volg: 'Husbands are warned repeatedly against the other woman's allure. No wife is ever warned about a husband's fragile fidelity.' Volgens hierdie model is dit noodsaaklik vir 'n man om 'n vrou te hê sodat hy ryk, suksesvol en gelukkig kan wees en 'n lang en goedversorgde lewe kan hê. Spreuke sê byvoorbeeld dat knap vroue baie werd is Hulle waarde word selfs meer as dié van edelstene geskat (Spr 31:10) (kyk Dreyer \& Van Aarde 2007:637). Thatcher (1999) maak die afleiding dat, alhoewel:

... a marriage is a source of blessing for the husband, it is also a source of grief for him. While a wife is a necessity, she is a dubious one. (bl. 82)

Die afleiding word gemaak op grond van die negatiewe siening van vroue in Prediker 25:16-26. Thatcher (1999) beskryf dit soos volg:

... a wife who refuses to submit uncomplainingly to her husband's demands is worse than a snake, her beauty is a source of deceit; dependence on her enslaves him ... (bl. 82)

Tog is daar in Spreuke ' $n$ figuur wat vreemd is aan die patriargale samelewing, naamlik 'Sophia' of 'Chokma' of 'Wysheid'. Stuart (2006) stel dit soos volg:

Here we are presented with a female figure who is somehow with the Lord at the beginning, somehow brought forth before creation and somehow coexisting with him like a child or master workman, separate and yet intimately connected. (bl. 327)

'Die konteks van Spreuke 1-9 toon egter duidelik dat die manier waarop die stem van "Wysheid" geposisioneer word, die patriargale sisteem ondersteun het' (Dreyer \& Van Aarde 2007:637). 
Thatcher (1999:83) vind die model van 'die huwelik as 'n wêreldse vergunning' in Paulus se verstaan van die huwelik in 1 Korintiërs 7. Paulus gee raad aan die gemeente in Korinte ten opsigte van die hantering van 'n asketiese faksie wat geglo het dat die uitleef van seksualiteit ongewens is. Die beeld van die huwelik is hoofsaaklik negatief. 'Die huwelik is ... [net] 'n toegewing wat gemaak word om immorele optrede soos seksuele omgang buite die huwelik te vermy. Boonop is dit beter om ongetroud te bly, omdat die huwelik die teken is van wêreldsheid en dit 'n mens se aandag ... [wegtrek] van ... [God] se werk' (Dreyer \& Van Aarde 2007:638). Die huwelik is dus toelaatbaar, maar nie aan te bevele nie. Hierdie siening is vir meer as 'n millennium in die Christelike kerk gehandhaaf (Thatcher 1999:84).

Alhoewel die huwelik as die tweede beste keuse beskou word en dat om ongetroud te bly beter is, behoort Paulus se siening oor die gelykheid van man en vrou in die huwelik wat blyk uit hierdie teks, nie misgekyk te word nie:

Die man moet sy huweliksplig teenoor sy vrou nakom, en net so ook die vrou teenoor haar man. Die vrou beskik nie oor haar eie liggaam nie, maar die man; net so beskik die man ook nie oor sy eie liggaam nie, maar die vrou. Moenie vir mekaar omgang weier nie, behalwe met wedersydse toestemming en net vir 'n bepaalde tyd om julle aan die gebed te wy. (1 Kor 7:3-5a)

Hieruit blyk duidelik dat Paulus die man en vrou as gelyke vennote binne die huwelik beskou, veral op liggaamlike gebied. In Matteus en veral Lukas word die huwelik in 'n meer negatiewe lig gesien as wat by Paulus die geval is. In Lukas 20:34-36 is mense wat getrou het van hierdie wêreld en nie van die toekomstige wêreld nie. Hulle huwelikstatus stel eintlik hulle deelname aan die opstanding in gevaar (Dreyer \& Van Aarde 2007:639; kyk ook Thatcher 1999:8485). Volgens Lukas is Jesus self hierdie mening toegedaan. Daarom moet die huwelik sover moontlik vermy word.

In die Ou-Testamentiese boek, Hooglied, vind Thatcher (1999:85) sy laaste model vir die huwelik, naamlik dié van 'wedersydse passievolle liefde'. Die openlike, speelse en erotiese beelde wat in die boek gebruik word, het veroorsaak dat dit óf geïgnoreer is, óf onder die invloed van die Efesiërteks allegories verklaar is as die spirituele liefde van Christus vir die kerk. Uit Tom Gledhill (1994:28) se opsomming blyk die algemene persepsie van kommentatore dat dit gaan oor die huwelik eerder as net oor 'n erotiese verhouding: '... joyous, tentative explorations of love of the betrothed couple culminating in their marriage and full sexual union in 5:1.' Hooglied word 'ordentlik' gemaak deur hierdie kommentatore. Volgens Roland Murphy (1990:60) is daar egter geen werklike bewyse vir die argument dat Hooglied enigiets met die huwelik te doen het nie. Die outeur noem nêrens die huwelikstatus van die paartjie nie (kyk Dreyer \& Van Aarde 2007:639).

Dit is opmerklik dat die vrou in Hooglied eerste aan die woord kom (Hoogl 1:2-4). 'Sy vertel in kleurryke taal en meer dikwels as die man van haar vrese, drange en behoeftes. Sy is die een wat haar geliefde uitnooi tot intimiteit en meestal neem sy self die inisiatief' (Dreyer \& Van Aarde 2007:639; kyk ook Gledhill 1994:93). In die Hooglied-teks word die a-simmetriese verhouding tussen man en vrou, wat veral in die verbondsiening van die huwelik voorkom, op 'n subtiele manier ondermyn. Gledhill (1994:140) stel dit soos volg: 'This reciprocity, this mutuality is something that shines out from the Song, something of a protest against the male dominance and macho-masculinity which sin brought into the world.' Die paartjie se genot en vreugde word sonder verdere verwysing na die 'verwekking van kinders' genoem of dat dit is 'om God te behaag' (vgl. Dreyer \& Van Aarde 2007:640). Temas soos vrugbaarheid en voortplanting wat so dikwels in ander Ou-Testamentiese boeke voorkom, is skaars in Hooglied. Die geliefdes gee hulleself in totale toewyding aan mekaar. 'Die man en vrou vertel beide van die bevrediging en genot wat hulle in mekaar gevind het' (Dreyer \& Van Aarde 2007:640). Skoonheid word ook nie soos in die boek Esegiël 'n voorwaarde vir die vrou se waarde en waardering van die man nie. In Hooglied word sy geprys vir wie sy is (Thatcher 1999:87).

'Tog kan selfs die geliefdes van Hooglied nie die donker wolk van die onderdrukkende kultuur van die tyd ontsnap nie' (Dreyer \& Van Aarde 2007:640). Volgens King (2006) het die vrywillige prysgawe van hulle verskil in status en mag ook 'n negatiewe gevolg:

$\ldots$ in the course of eschewing difference, they have made themselves 'different' - deviant - in the public eye. Pursuing a vision of equality in desire and reciprocal self-offering, they have made themselves vulnerable to exclusion as outsiders, as 'queers'. (bl. 365)

Hulle optrede het die Israelitiese siening van ordelikheid en van geslagsrolle oorskry. Waar die vrou in die kultuur as die passiewe een beskou is, neem sy in Hooglied dikwels die inisiatief. Waar die man volgens die kultuur altyd in beheer moes bly, verloor hy in Hooglied soms beheer.

\section{Kerk in krisis}

Wêreldwyd het hoofstroomkerke in ' $n$ krisis beland omdat kerke uit voeling geraak het met 'n vinnig veranderende, namoderne wêreld waarin sekularisasie en desekularisasie 'n bepalende invloed het. Volgens Heitink (2007:356) sal kerke hulleself moet heroriënteer tot die situasie waarin hulle hulle bevind (vgl. Dreyer 2009:5). So 'n heroriëntasie is noodsaaklik as kerke wil voortbestaan en steeds relevant wil wees in vandag se wêreld (Dreyer, W.A. 2011:2; vgl. McGrath 2001:47). Dit is 'n dringende aangeleentheid, want kerke bevind hulle in 'n kairos-oomblik - (die tyd is ryp vir verandering) (Heitink 2007:20; vgl. Huber 1999:223). Die huidige stagnasie in die kerk is nie versoenbaar met die kerk as 'kerk van die Here' nie (Heitink 2007:20-23). Volgens die grondpatrone van die kerk en metafore wat kerkwees beskryf as 'volk van God wat onderweg is', 'die kerk as liggaam van Christus', 'die kerk as tempel van die Gees', en as 'bruid van Christus' (Heitink 2007:25-28), behoort die kerk dinamies te wees en in beweging te bly. Die kerk behoort nie net saam te beweeg met verandering in die wêreld nie, maar behoort ' $n$ insiggewende en rigtinggewende funksie te kan vervul te midde van verandering. 
Die tyd en omstandighede waarin die kerk leef, dring aan op nuwe denke en aanpassing (kyk Van Aarde \& Dreyer 2011:8).

Hierdie transformasie vir Dreyer (2009:5) behels dat die kerk sal afstand doen van dominante meesternarratiewe en onbevange sal luister na die klein verhale van mense. Hierdie heroriëntasie is ook nodig ten opsigte van die lewensterreine in die samelewing wat in die geskiedenis onder kerklike beheer was, soos byvoorbeeld die huwelik. In 'n artikel getiteld, 'Die Kerk, die huwelik en seks - 'n morele krisis?', vra T.F.J. Dreyer (2008:483) of die kerk met die 'tradisionele' verstaan van die huwelik en seksuele verhoudings mense nog kan begelei om sinvolle en verantwoordelike keuses as gelowiges te maak. Dreyer in Van Aarde en Dreyer (2011:9) stel dit soos volg: 'Hoe ongemaklik die vraag ook al is, sal die kerk weer opnuut moet besin oor die mees effektiewe uiterlike vorm van die huwelik vir ons tyd.'

\section{Ekofeministiese familie-etiek}

As 'n alternatief vir die instandhouding van die heteronormatiewe hegemoniese patriargale monogame huwelik, stel Radford Ruether (2001:181-230) 'n ekofeministiese familie-etiek voor. In Radford Ruether (2001:181) se eko-feministiese familie-etiek gaan dit vir haar oor '[r]eimagining families: home, work, gender, and faith'. Hedendaagse huishoudings en gesinne is anders saamgestel as die tradisionele voorbeeld. Saamgestelde gesinne is ' $n$ komplekse familie-netwerk as gevolg van egskeidings of tweede huwelike (Radford Ruether 2001:182-184). Vroue se situasie het baie verander. Vir ongeveer die eerste 20 jaar van hulle lewe is vroue deel van hulle ouers se huishouding, afhanklik van hulle ouers se inkomste, terwyl hulle verder studeer en dikwels eers hulle nagraadse studies klaarmaak voordat hulle trou of kinders het. Drie veranderinge het plaasgevind tussen 1900-2000 wat die gesig van die huwelik verander het. Eerstens het ekonomiese produksie uit die huishouding verdwyn, daar word nie meer as 'n span saam gewerk om die huishouding te onderhou nie. Tweedens het vroue selfstandige regspersone geword wat kan stem en hulle eie eiendom besit. Derdens het wettige onafhanklikheid dit vir vroue moontlik gemaak om ekonomies selfversorgend te wees. Hierdie veranderinge het die redes waarom vroue trou, verander. Radford-Ruther (2001) verwoord dit soos volg:

Taken together, these changes have recast marriage as a love relationship to be entered into primarily for companionship and only secondarily for child rearing. Because many women can be self-supporting, unhappy marriages need no longer be endured. It is now more often women than men who make the decision to divorce. (bl. 188-189)

Terwyl lewenslange monogame huwelike steeds as die ideaal gesien word, is die realiteit dikwels anders. Die realiteit bestaan uit wat Radford Ruether (2001:189) 'serial monogamy' noem. Die redes vir hierdie verskynsel is weereens omdat vroue nie meer ekonomies en wetlik van mans afhanklik is nie en omdat mans sowel as vroue twee keer solank leef as voorheen en deur meer lewensfases gaan. Nie net mans nie, maar ook vroue ontgroei hulle lewensmaats. Die hedendaagse verwagting dat die huwelik vervullende kameraadskap moet bied, dra ook daartoe by dat egskeidings toeneem. Wanneer die huwelik nie aan daardie verwagting voldoen nie, word dit getermineer. Die veranderings in die samelewing en werksomgewing plaas verdere druk op huishoudings:

For ... both men and women work expectations have expanded from an eight- to a ten- or even a twelve-hour day .... Women who seek well-paid professions are on the same treadmill, while also carrying the primary burden of "family time" ${ }^{\prime} .$. It is this contradictory tension between work time and family time that defines the greatest problem facing families today - for women particularly, but also for men. (Radford Ruether 2001:204-205)

Die oplossing vir hierdie probleem sal nie gevind word in klein aanpassings wat gemaak word nie, maar verg 'n radikale transformasie van die sosiale sisteem. Dit raak alle verhoudings, werk en gesin, asook by uitstek die verhouding tussen man en vrou. Hate is not a family value. Só lees 'n bufferplakker wat kritiek op die Christian Right beweging se family values veldtog lewer teen die einde van die twintigste eeu. Die beweging se perspektief of familie waardes was op die 'skeppingsorde' gebaseer en met behulp van hierdie perspektief of waardes wou die beweging die patriargale hiërargie van mans oor vroue legitimeer. Onderliggend aan patriargale waardes lê die waarde van ekskluwisme (Radford Ruether 2001:206). Hiervolgens is daar net een 'regte familie model' en dit is die heteronormatiewe hegemoniese patriargale monogame huwelik. Die vooronderstelling is dat die hoofskap van die man die God-gegewe norm is. Dit word gebruik om die homofobie en vrouehaat wat daaruit voortspruit, te regverdig.

Teenoor die instandhouding van hierdie model van die huwelik en/of familie en/of huishouding, stel Radford Ruether (2001) 'n eko-feministiese familie-etiek voor, wat gebaseer is op:

... the equality and partnership of men and women in family, work, and society, and on the reconfiguring of work-family relations and economic and political hierarchies to foster a more equitable sharing of wealth within sustainable communities. (bl. 207)

Die basiese beginsel van 'n eko-feministiese etiek is die erkenning van die volwaardige en gelyke menswees van vroue in vennootskap met mans. Feministiese etiek verwerp beide gender-hiërargie en gender-komplementariteit, want beide doen afbreuk aan die volwaardige persoonskap van vroue en mans.

\section{Erkenning Mededingende belange}

Die outeurs verklaar dat hulle geen finansiële of persoonlike verbintenis het met enige party wat hulle nadelig kon beïnvloed in die skryf van hierdie artikel nie.

\section{Outeursbydrae}

A.B. (Universiteit van Pretoria), was verantwoordelik vir die teksbydraes wat gelewer is, Y.D. (Universiteit van Pretoria), was verantwoordelik vir die supervisie daarvan. 


\section{Literatuurverwysings}

Anderson, B.W., 1993, s.v. 'Covenant', in B.M. Metzger \& M.D. Coogan (eds.), The Oxford companion to the Bible, Oxford University Press, Oxford, pp. 138-139.

Barton, S.C., 1996, 'Is the Bible good news for human sexuality? Reflections on method in Biblical interpretation', in A. Thatcher \& E. Stuart (eds.), Christian perspectives on sexuality and gender, pp. 4-13, Eerdmans, Grand Rapids, MI.

Batey, R., 1961, The church, the bride of Christ, published on demand by University Microfilms, University Microfilms Limited, High Wycomb, England, A Xerox Company, Ann Arbor, MI.

Batey, R.A., 1971, New Testament nuptial imagery, Brill, Leiden.

Bolle, K., 1987, s.v. 'Hieros gamos', in M. Eliade (ed.), Encyclopaedia of religion, MacMillan, New York, vol. 6, pp. 317-321.

Botha, A. \& Dreyer, Y., 2007, 'Demistifikasie van die metafoor "Kerk as Bruid", HTS Teologiese Studies/Theological Studies 63(3), 1239-1274. http://dx.doi. org/10.4102/hts.v63i3.251

Bouyer, L., [1970] 2011, The church of God: Body of Christ and temple of the Spirit, Ignatius Press, San Francisco, CA.

Brooten, B.J., 2003, 'Nature, law, and custom in “'Augustine's on the good of marriage"', in S. Matthews, C. Briggs Kittredge \& M. Johnson-DeBaufre (eds.), Walk in the ways of wisdom: Essays in honor of Elisabeth Schüssler Fiorenza, pp. 181-193, Trinity Press International, Harrisburg, PA.

Brown, R., 1990, Marriage annulment in the Catholic Church, Kevin Mayhew, Bury St Edmunds.

Budin, S.L., 2008, The myth of sacred prostitution in antiquity, Cambridge University Press, Cambridge. http://dx.doi.org/10.1017/CB09780511497766

Chavasse, C., [1939] 1940, Bride of Christ: An enquiry into the nuptial element in Early Christianity, Faber, London. PMid:20782892; PMCid:PMC2176290

Clark, D., \& Haldane, J.D., 1990, Wedlocked? Intervention and research in marriage, Polity Press, Cambridge.

Cooper-White, P., 1995, The cry of Tamar: Violence against women and the church's response, Fortress Press, Minneapolis, MN.

Deflem, M., 1991, 'Ritual, anti-structure, and religion: A discussion of Victor Turner's processual symbolic analysis', Journal for the Scientific Study of Religion 30(1) 1-25. http://dx.doi.org/10.2307/1387146

Dreyer, A.E. \& Van Aarde, A.G., 2007, 'Bybelse modelle van die huwelik: 'n Kritiese perspektief', HTS Teologiese Studies/Theological Studies 63(2), 625-651. http:// dx.doi.org/10.4102/hts.v63i2.226

Dreyer, T.F.J., 2008, 'Die Kerk, die huwelik en seks - 'n morele krisis?', HTS Teologiese Studies/Theological Studies 64(1), 483-496. http://dx.doi.org/10.4102/hts. Studies/The
v64i1.9

Dreyer, T.F.J., 2009, "n Kerk met karakter: Die perspektief van Gerben Heitink', HTS Teologiese Studies/Theological Studies 65(1), Art. \#315, 5 pages. http://dx.doi. org/10.4102/hts.v65i.315

Dreyer, W.A., 2011, 'Historiese-vergelykende ekklesiologie - op pad na 'n omvattende praktiese ekklesiologie', HTS Teologiese Studies/Theological Studies 67(3), Art. \#1083, 8 pages. http://dx.doi.org/10.4102/hts.v67i3.1083

Dreyer, Y., 2008, "The "sanctity" of marriage - archaeology of a socio-religious construct: Mythological origins, forms and models', HTS Teologiese Studies/ Theological Studies 64(1), 499-527. http://dx.doi.org/10.4102/hts.v64i1.10

Dreyer, Y., 2011, 'Women's spirituality and feminist theology: A hermeneutic of suspiscion applied to "patriarchal marriage"', HTS Teologiese Studies/Theological Studies 67(3), Art. \#1104, 5 pages. http://dx.doi.org/10.4102/hts.v67i3.1104

Ekelaar, J., 2006, Family law and personal life, Oxford University Press, Oxford.

Gledhill, T., 1994, The message of the Song of Songs, Inter-Varsity Press, Leicester. PMCid:PMC1968759

Glendon, M.A., 1989, The transformation of family law: State, law, and family in the United States and Europe, University of Chicago Press, Chicago, IL.

Haughton, R., 1987, 'The meaning of marriage in women's new consciousness', in W.P. Roberts (ed.), Commitment to partnership: Explorations of the theology of marriage, pp. 141-154, Paulist Press, New York, NY.

Heitink, G., 2007, Een kerk met karakter: Tijd voor heroriëntatie, Kok, Kampen. PMid:17973879

Hodgson, P.C., 1994, Winds of the Spirit: A constructive Christian theology, SCM Press, London.

Huber, W., 1999, Kirche in der Zeitenwende: Gesellschaftlicher Wandel und Erneuerung der Kirche, Verlag Bertelsmann Stiftung, Gütersloh.

Jacobs-Malina, D., 1993, Beyond patriarchy: The images of family in Jesus, Paulist Press, New York, NY
King, C., 2006, 'Song of Songs', in D. Guest et al. (eds.), The Queer Bible commentary, pp. 356-370, SCM, London. PMid:17169490

Ledegang, F., 2001, Mysterium ecclesiae: Images of the church and its members in origin, Peeters, Leuven (Bibliotheca Ephemeridum Theologicarum Lovaniensium).

Mackin, T., 1982, Marriage in the Catholic Church: What is marriage?, Paulist Press, New York, NY. PMid:6286772

Malina, B.J., 1993, The New Testament world: Insights from cultural anthropology, rev. edn., Westminster/John Knox, Louisville, KY.

Matouschek, N. \& Rasul, I., 2008, 'The economics of the marriage contract: Theories and evidence', in Journal of Law and Economics 51, 59-110. http://dx.doi org $/ 10.1086 / 588596$

McGrath, A.E., 2001, Christian theology - An introduction, Blackwell Publishing, Malden, MA.

Milner, B.C., 1970, Calvin's doctrine of the church, Brill, Leiden

Minear, P.S., [1960] 2004, Images of the church in the New Testament, with foreword by L. Keck, Westminster John Knox, Louisville, KY. (The New Testament Library). PMCid:PMC516469

Mollenkott, V.R., 2003, 'Emancipative elements in Ephesians 5:21-33: Why feminist scholarship has (often) left them unmentioned, and why they should be emphasized', in A. Levine \& M. Blickenstaff (eds.), A feminist companion to the Deutero-Pauline epistles, pp. 37-58, T\&T Clark International, New York, NY.

Moore, Z., 2002, Introducing feminist perspectives on pastoral theology, Sheffield Academic Press, New York, NY.

Mouton, E., 1995, 'Reading a New Testament document ethically: Toward an accountable use of Scripture in Christian ethics, through analyzing the transformative potential of the Ephesians epistle', doctoral dissertation, Department New Testament, University of the Western Cape.

Mouton, E., 2003, '(Re)describing reality? The transformative potential of Ephesians across times and cultures', in A. Levine \& M. Blickenstaff (eds.), A feminist companion to the Deutero-Pauline epistles, pp. 59-87, T\&T Clark International, New York, NY.

Murphy, R.E., 1990, Commentary on the Book of Canticles or Song of Songs, Fortress Press, Minneapolis, MN.

Osiek, C., 2002, 'The Bride of Christ (Ephesians 5:22-33): A problematic wedding', Biblical Theology Bulletin 32(1), 29-39. http://dx.doi.org/10.1177/014610790203200106

Palmer, P.F., 1972, 'Christian marriage: Contract or covenant?' Theological Studies 33(4), 617-665.

Parkman, A.M., 1993, 'Reform of the divorce provisions of the marriage contract', BYU Journal of Public Law 8(1), 91-106.

Radford Ruether, R., 2001, Christianity and the making of the modern family, SCM Press, London.

Schüssler Fiorenza, E., 1991, 'Marriage', in F. Schüssler Fiorenza \& J.P. Galvin (eds.), Systematic theology: Roman Catholic perspectives, vol. 2, pp. 305-346, Fortress Press, Minneapolis, MN.

Schüssler Fiorenza, E., 1993, Discipleship of equals, Crossroad, New York, NY.

Stuart, E., 2006, 'Proverbs', in D. Guest, R.E. Goss, M. West \& T. Bohache (eds.), The Queer Bible commentary, pp. 325-337, SCM Press, London.

Tanzer, S.J., 1994, 'Ephesians', in E. Schüssler Fiorenza (ed.), Searching the Scriptures, volume 2: A feminist commentary, pp. 325-348, Crossroad, New York.

Taylor, M.K., 1990, Remembering Esperanza: A cultural-political theology for North American praxis, Orbis Books, Maryknoll, NY.

Thatcher, A., 1999, Marriage after modernity: Christian marriage in postmodern times, Sheffield Academic Press, Sheffield.

Van Aarde, A.G. \& Dreyer, T.F.J., 2011, 'Die pendule subjektiwiteit-objektiwiteit in die teologie van Theuns Dreyer - 'n Dialoog'. HTS Teologiese Studies/Theological Studies 67(3), Art. \#1172, 11 pages. http://dx.doi.org/10/4102/hts.v67i31172

Van Gennep, A., [1909] 1960, The rites of passage, Routledge \& Keegan Paul, London.

Weeks, J., 1995, Invented moralities: Sexual values in an age of uncertainty, Polity Press, Cambridge, MA.

Weems, R.J., 1989, 'Gomer: Victim of violence or victim of metaphor?', Semeia 47, 87-104.

Witte, J., 1997, From sacrament to contract: Marriage, religion, and law in the Western tradition, Westminster John Knox, Louisville, KY.

Yee, G.A., 1992, 'Hosea', in C.A. Newsom \& S.H. Ringe (eds.), The women's Bible commentary, pp. 201-215, Westminster, Louisville, KY.

Yee, G.A., 2001, 'She is not my wife and I am not her husband: A materialist analysis of Hosea 1-2', Biblical Interpretation IX, 345-383. http://dx.doi. org/10.1163/15685150152695272 